Thorax, 1978, 33, 457-463

\title{
The cardiorespiratory response to exercise in thoracic scoliosis
}

\author{
J M SHNEERSON
}

From the Department of Respiratory Physiology, Cardiothoracic Institute, Brompton Hospital, London SW3 6HP, UK

Shneerson, J M (1978). Thorax, 33, 457-463. The cardiorespiratory response to exercise in thoracic scoliosis. Twenty-six subjects with thoracic scoliosis due to various causes have been investigated. They all performed a progressive exercise test under standardised conditions, and their maximum oxygen uptake $\left(\mathrm{V}_{2}\right.$ max), blood gases, and ventilatory and heart rate responses were observed.

The $\mathrm{Vo}_{2}$ max was significantly below normal and was proportional to the forced expiratory volume in one second $\left(\mathrm{FEV}_{1}\right)$ and maximum exercise ventilation ( $\left.\mathrm{V}_{\mathrm{E}} \mathrm{max}\right)$. Exercise was limited by ventilatory factors in $80 \%$ of the subjects who exercised maximally. VE max was diminished, but the dyspnoeic index was normal. The minute ventilation ( $\mathrm{V} E)$ at any given $\mathrm{V}_{2}$ was about $20 \%$ greater than normal. This hyperventilation taken with the low VE max explains why exercise is usually ventilation-limited in these subjects.

Tidal volume $\left(V_{T}\right)$ increased linearly with ventilation until $V_{T} \max$ was reached. The tidal volumes at any given ventilation were less than normal, but when expressed as a percentage of vital capacity (VC) they were above normal. The heart rate increased more rapidly than normal, but this appears to be a physiological result of the small muscle mass of these subjects and not a pathological response.

Hippocrates noted that hunchbacks were "affected with difficulty of breathing." Hutchinson (1844) showed that their vital capacity (VC) was diminished, and Anthony (1930), using a hydrogen mixing technique, showed the small total lung capacity, residual volume, and functional residual capacity. Brief accounts of the heart rate (HR) and ventilation responses to exercise were reported by Samuelsson (1950), Bergofsky et al (1959), and Wlodyka and Wierusz (1974), but in each case the number of patients was small and little detail of the type of exercise was given.

Taylor et al (1963) have shown that the results of exercise tests are unreliable unless they are performed under carefully standardised conditions. Recently, exercise tests in which the work rate is progressively increased have largely taken the place of steady state tests for clinical use (Godfrey, 1974) and values for normal subjects have been obtained (eg Spiro, 1975). In the present study the subjects exercised on a bicycle ergometer against progressively increasing loads, and their heart rate and respiratory responses have been described in detail.

\section{Subjects and methods}

Twenty-six subjects (10 male and 16 female) with thoracic scoliosis gave informed consent to be studied. Their ages ranged from 13 to 67 years (mean $28 \cdot 8$ ). The scoliosis was congenital in five, idiopathic in six, followed poliomyelitis or other neurological disease in nine, and was associated with Marfan's syndrome in three and neurofibromatosis in three. Fifteen had previously undergone spinal fusion. None had any cardiac or respiratory disease complicating the scoliosis.

The angle of scoliosis was determined by the method of Cobb (1948). The patients were weighed and their fat free mass determined by the formulae of Durnin and Womersley (1974) from the skinfold thickness over the biceps muscles. The FEV 1 and vital capacity were measured with a dry spirometer (Vitalograph) and the maximum voluntary ventilation over $15 \mathrm{~s}$ with a low-resistance 9-litre wet spirometer (P K Morgan). The latter value was multiplied by four and converted to BTPS to give the maximum ventilatory volume MVV $(1 / \mathrm{min})$. The 
mean anthropometric and spirometric data are shown in table 1 .

An arterial cannula was used to obtain blood samples for gas analysis on an IL 213 blood gas analyser. Exercise was performed while sitting on an electrically-braked ergometer (Lode). The inspiratory minute volume was measured by a Parkinson Cowan CD4 dry gas meter with an electrical output to a direct-writing ink-jet recorder (Mingograf 81) (fig 1). The gas meter was calibrated with a sinusoidal pump operating at various stroke volumes and frequencies. The gas meter was connected by wide-bore tubing to a low resistance two-way respiratory valve $(P K$ Morgan 71522) with a dead space of $60 \mathrm{ml}$. The resistance of the system to inspiration was 0.43 $\mathrm{cmH}_{2} \mathrm{O}$ at $10 \mathrm{l} / \mathrm{min}$ and $0.95 \mathrm{cmH}_{2} \mathrm{O}$ at $70 \mathrm{l} / \mathrm{min}$. The expired gas passed through wide-bore connecting tubing to a mixing chamber of $7 \cdot 81$ capacity containing an electrically-driven fan. A sample of the mixed expired gas was dried with magnesium perchlorate and passed through a paramagnetic Servomex OA 150 oxygen analyser and an infrared absorption $\mathrm{CO}_{2}$ analyser (URAS 4). The Servomex response was linear over the range 14-21\% $\mathrm{O}_{2}$ and the URAS 4 over the range $0-5 \% \mathrm{CO}_{2}$. The $95 \%$ response times of both to a square wave of gas leaving the mixing chamber were four seconds. Both machines were $\bar{\sigma}$ connected electrically to the Mingograf and were $\frac{\bar{s}}{6}$ re-calibrated before and after each test. Oxygen $\mathbb{D}$ uptake was calculated using a nitrogen correction and agreed within $5 \%$ with simultaneous measurements based on chemical analyses of expired gas collected in Douglas bags.

The patients were familiarised with the apparatus on the day before the tests. They rested on the erg- $\vec{x}$ ometer until their inspired ventilation, mixed expired gas composition, and heart rate were steady. They then began pedalling, initially at a work rate of 15 watts. The work rate was increased by 15 watts each जु minute and the patients were encouraged to keep 을 exercising until limited by severe dyspnoea or tired- ness, a respiratory rate above $40 / \mathrm{min}$, and a pulse rate above $170 / \mathrm{min}$. Twenty patients achieved maximal co exercise. Exercise was considered "ventilation- क् limited" if it was stopped because of dyspnoea $\vec{\varphi}$ with a steady tidal volume, respiratory rate $>40 / \infty$ min, and pulse $<170$ beats $\min ^{-1}$ and a rapid fall in ventilation after exercise.

The slope of the relationship between $\dot{V} E$ and $H R$ and the $\dot{\mathrm{VO}}_{2}$ was calculated from the linear part of the

Table 1 Anthropometric and spirometric data

\begin{tabular}{|c|c|c|c|c|c|c|c|c|c|}
\hline Group & & $\begin{array}{l}\text { Weight } \\
(k g)\end{array}$ & $\begin{array}{l}\text { Fat free mass } \\
(k g)\end{array}$ & $\begin{array}{l}\text { Height } \\
(\mathrm{cm})\end{array}$ & $\begin{array}{l}\text { Arm span } \\
(\mathrm{cm})\end{array}$ & $\begin{array}{l}\text { Angle of } \\
\text { scoliosis } \\
\text { degrees }\end{array}$ & $\begin{array}{l}F E V_{1} \\
(l)\end{array}$ & $\begin{array}{l}V C \\
(l)\end{array}$ & $\begin{array}{l}M V V \\
\left(l \min ^{-1}\right)\end{array}$ \\
\hline $\begin{array}{l}\text { Male } \\
(n=12)\end{array}$ & $\begin{array}{l}\text { Range } \\
\text { Mean } \\
\text { SD }\end{array}$ & $\begin{array}{l}20-74 \\
50 \cdot 8 \\
14 \cdot 1\end{array}$ & $\begin{array}{l}19-59 \cdot 9 \\
42 \cdot 1 \\
10 \cdot 4\end{array}$ & $\begin{array}{c}123-169 \\
155 \cdot 5 \\
11 \cdot 8\end{array}$ & $\begin{array}{l}138-192 \\
171 \\
15 \cdot 1\end{array}$ & $\begin{array}{l}20-130 \\
75 \cdot 4 \\
30 \cdot 3\end{array}$ & $\begin{array}{l}0 \cdot 50-2 \cdot 85 \\
1 \cdot 50 \\
0 \cdot 70\end{array}$ & $\begin{array}{l}0.55-2.90 \\
1.69 \\
0.73\end{array}$ & $\begin{array}{l}23 \cdot 1-143 \cdot 4 \\
61 \cdot 4 \\
36 \cdot 6\end{array}$ \\
\hline $\begin{array}{l}\text { Female } \\
(n=14)\end{array}$ & $\begin{array}{l}\text { Range } \\
\text { Mean } \\
\text { SD }\end{array}$ & $\begin{array}{l}22 \cdot 5-58 \\
38 \cdot 4 \\
9 \cdot 2\end{array}$ & $\begin{array}{l}19 \cdot 3-44 \cdot 5 \\
31 \cdot 0 \\
6 \cdot 2\end{array}$ & $\begin{array}{c}130 \cdot 5-162 \\
146 \cdot 5 \\
9 \cdot 0\end{array}$ & $\begin{array}{c}132-200 \\
159 \cdot 6 \\
17 \cdot 3\end{array}$ & $\begin{array}{l}25-115 \\
68 \cdot 9 \\
25 \cdot 7\end{array}$ & $\begin{array}{l}0.45-2 \cdot 85 \\
1 \cdot 32 \\
0.62\end{array}$ & $\begin{array}{l}0.55-2.95 \\
1.51 \\
0.65\end{array}$ & $\begin{array}{l}18 \cdot 1-121 \cdot 0 \\
57 \cdot 1 \\
28 \cdot 3\end{array}$ \\
\hline
\end{tabular}

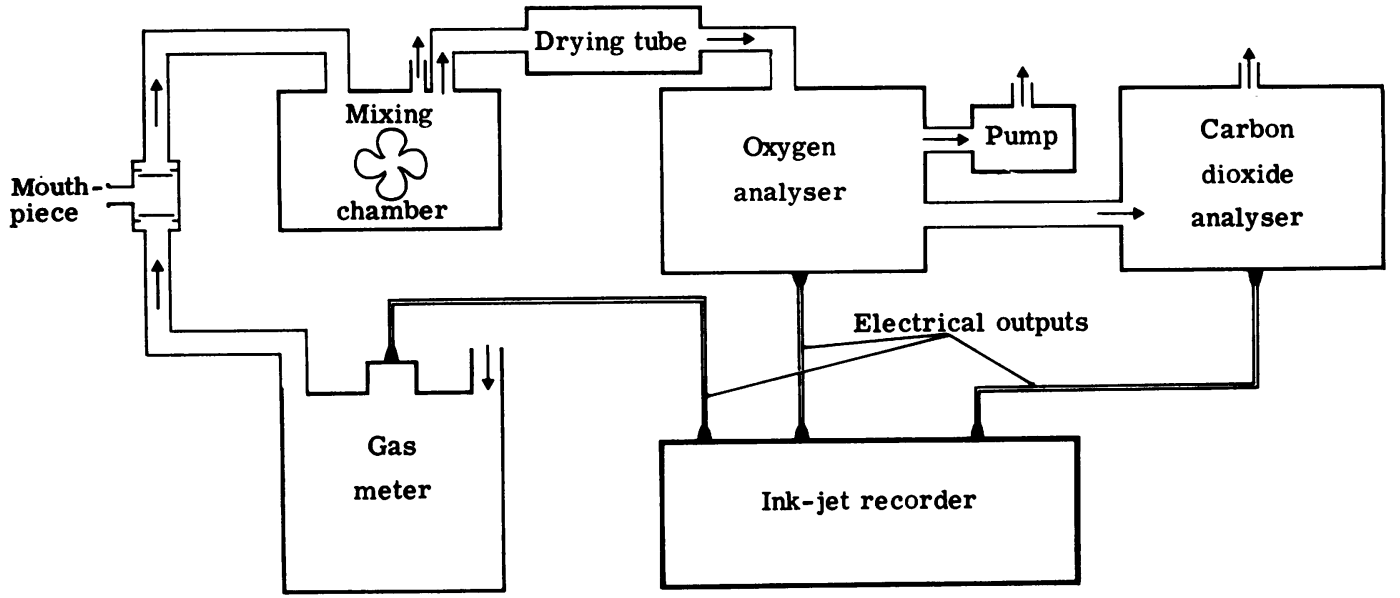

Fig 1 Circuit diagram of equipment used to measure ventilation and gas exchange. 
graphs. The $\dot{V} E$ and $H R$ responses were expressed as maximal values (VE max; HR max) and at interpolated values of $\dot{\mathrm{V}}_{2}$ of $0.751,1.01$, and $1.51\left(\dot{V}_{E_{0}} \cdot 75\right.$, $\dot{\mathrm{V}}_{1} \cdot 0, \dot{V}_{E_{1} \cdot 5} ; \mathrm{HR}_{0.75}, \mathrm{HR}_{1 \cdot 0}, \mathrm{HR}_{1.5}$ ) (Cotes, 1969; Spiro et al, 1974). The pattern of breathing was assessed by plotting $\dot{V}_{E}$ against $V_{T}$, as recommended by Hey et al (1966). These authors found that the relationship could be described as $\dot{V} E=m\left(V_{T}-k\right)$ $1 / \mathrm{min}$ where $\mathrm{m}$ has the units of frequency and $\mathrm{k}$ of volume.

Submaximal tidal volumes have been expressed as the slope $\dot{V}_{E} / V_{T}(m)$ and as tidal volumes at $\dot{V}_{E}$ of 20 and $30 \mathrm{l} / \mathrm{min}\left(\mathrm{V}_{\mathrm{T20}}, \mathrm{V}_{\mathrm{T}} \mathbf{3 0}\right)$.

\section{Results}

MAXIMAL OXYGEN UPTAKE (V்o 2 max)

$\dot{V}_{2}$ max ranged from 11.0 to $34.1 \mathrm{ml} / \mathrm{min} / \mathrm{kg}$ body weight $(n=20$, mean $=24 \cdot 8, S D=6 \cdot 6)$. For the men it ranged from 11.0 to $33.7 \mathrm{ml} / \mathrm{min} / \mathrm{kg}$ body weight $(\mathrm{n}=9$, mean $=25 \cdot 7, \mathrm{SD}=6 \cdot 0, \mathrm{SEM}=2 \cdot 0)$ and for the women from 13.2 to $34.1 \mathrm{ml} / \mathrm{min} / \mathrm{kg}$ body weight $(\mathrm{n}=11$, mean $=24 \cdot 3, \mathrm{SD}=5 \cdot 9, \mathrm{SEM}=1 \cdot 8)$. Both these values are statistically significantly lower $(P<0.01)$ than an age-matched group of normal controls (Bruce et al, 1973).

\section{MAXIMAL EXERCISE VENTILATION (VंE max)}

Sixteen subjects were forced to stop exercising by ventilatory factors. VंE max ranged from 13.13 to $76.05 \mathrm{l} / \mathrm{min}(\mathrm{n}=16$, mean $=36.41, \mathrm{SD}=17 \cdot 73)$. The ratio of VE max to the MVV (ie the dyspnoeic index) was $0.70(n=16, S D=0.14)$. The difference between those with paralytic scoliosis $(n=6$, mean $=0.62$, $\mathrm{SEM}=0.04)$ and the non-paralytic $(\mathrm{n}=10$, mean $=$ $0 \cdot 74$, SEM $=0.05$ ) was not significant.

\section{MINUTE VENTILATION ('ंE)}

The response of the minute ventilation ( $\left.\dot{V}_{E}\right)$ during exercise is displayed in table 2 . The subjects have been subdivided according to their age and sex for com-

Table 2 Response of ventilation during increasing work rate test

\begin{tabular}{|c|c|c|c|c|}
\hline Index & Group & $n$ & Mean & $S D$ \\
\hline $\begin{array}{c}\text { Slope } \dot{V} E / \dot{V}_{2} \\
\left(L / L \dot{V} O_{2}\right)\end{array}$ & $\begin{array}{l}\text { Men, 20-39 years } \\
\text { Men, > 20 years } \\
\text { Women, 20-39 years }\end{array}$ & $\begin{array}{r}7 \\
10 \\
12\end{array}$ & $\begin{array}{l}27 \cdot 4 \\
28 \cdot 1 \\
30 \cdot 3\end{array}$ & $\begin{array}{l}4 \cdot 2 \\
4 \cdot 2 \\
6 \cdot 0\end{array}$ \\
\hline$\dot{\mathrm{V}} \mathrm{E}_{0.75}\left(1 \mathrm{~min}^{-1}\right)$ & $\begin{array}{l}\text { Men, 20-39 years } \\
\text { Men, > 20 years } \\
\text { Women, 20-39 years }\end{array}$ & $\begin{array}{l}6 \\
9 \\
9\end{array}$ & $\begin{array}{l}21 \cdot 1 \\
21 \cdot 2 \\
23 \cdot 1\end{array}$ & $\begin{array}{l}2 \cdot 1 \\
2 \cdot 2 \\
2 \cdot 4\end{array}$ \\
\hline$\dot{V}_{E_{1.0}}\left(1 \mathrm{~min}^{-1}\right)$ & $\begin{array}{l}\text { Men, 20-39 years } \\
\text { Men, > } 20 \text { years } \\
\text { Women, 20-39 years }\end{array}$ & $\begin{array}{l}5 \\
7 \\
8\end{array}$ & $\begin{array}{l}27 \cdot 8 \\
27 \cdot 5 \\
31 \cdot 1\end{array}$ & $\begin{array}{l}3 \cdot 1 \\
2 \cdot 6 \\
3 \cdot 8\end{array}$ \\
\hline$\dot{V}_{E_{1.5}}\left(1 \mathrm{~min}^{-1}\right)$ & $\begin{array}{l}\text { Men, 20-39 years } \\
\text { Men, }>20 \text { years } \\
\text { Women, 20-39 years }\end{array}$ & $\begin{array}{l}2 \\
3 \\
1\end{array}$ & $\begin{array}{l}41 \cdot 8 \\
42 \cdot 7 \\
53 \cdot 1\end{array}$ & $\begin{array}{l}1 \cdot 1 \\
1 \cdot 8 \\
-\end{array}$ \\
\hline
\end{tabular}

parison with Spiro's (1975) normal values. VंE0.75, 1.0, 1.5 were all significantly greater $(P<0.05)$ in the women than in the men, although there was no appreciable difference in slope $\dot{\mathrm{V}}_{\mathrm{E}} / \dot{\mathrm{VO}}_{2}$ between the sexes.

In both sexes $\dot{V}_{E_{0}} \cdot 75,1.0,1.5$ were significantly greater than normal (Spiro, 1975) $\left(\mathrm{P}<0.05\right.$ for $\mathrm{V}_{\mathbf{0}} \cdot 75$, 1.0 in men; $P<0.01$ for $\dot{V}_{E_{0} .75,1.0}$ in women and $\dot{V}_{E_{1} .5}$ in both sexes). All the values were about $20 \%$ greater than normal. Slope $\dot{V} E / V_{2}$ did not differ from normal.

\section{PATTERN OF VENTILATION}

The tidal volume increased linearly with $\dot{V E}$ in each patient until $\mathrm{V}_{\mathrm{T}} \max$ was reached. The response of $V_{T}$ was expressed by the method of Hey et al (1966) (fig 2). All 26 patients were used in this plot. For the men and women aged 20-39 years the differences between $\mathrm{k}, \mathrm{m} . \mathrm{VC}, \mathrm{V}_{\mathrm{T} 30}, \mathrm{~V}_{\mathrm{T} 30} / \mathrm{VC} \times 100 \%, \mathrm{~V}_{\mathrm{T}} \max$, and $V_{T} \max / V C \times 100 \%$ were not significant. The differences in $\mathrm{m}, \mathrm{V}_{\mathrm{T} 20}$, and $\mathrm{V}_{\mathrm{T} 20} / \mathrm{VC} \times 100 \%$ were significant $(\mathrm{P}<0.05)$ (table 3).

The results show interesting differences from the normal subjects of Spiro et al (1974) (fig 2). The intercept on the $\mathrm{x}$ axis, $\mathrm{k}$, is smaller than normal ( $P<0.05$ for men; $P<0.01$ for women), but the slope of $V_{E} / V_{T}(m)$ is greater than normal $(P<0.05$ for men; $P<0.01$ for women). $V_{T 20}, V_{T 30}$, and $V_{T} \max$ are all below normal in both sexes $(\mathrm{P}<0.01)$.

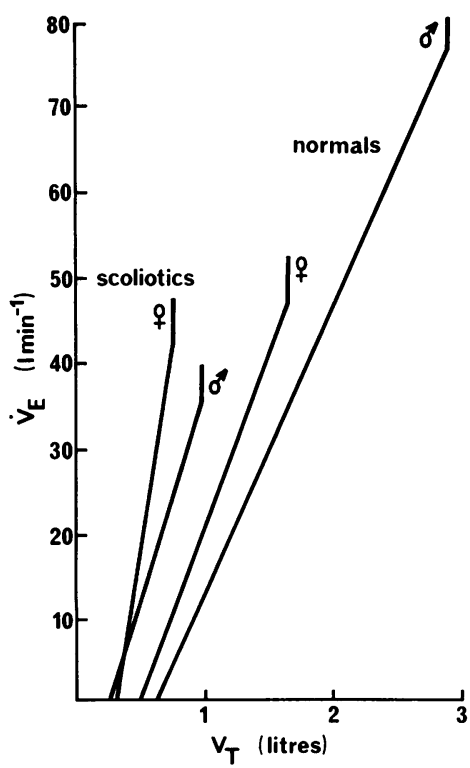

Fig 2 Relationship between $\dot{V}_{E}$ and tidal volume in all 26 scoliotic patients and normal subjects (Spiro, 1975), calculated from mean slopes, intercepts, and maximal tidal volumes. 
Table 3 Indices of tidal volume during increasing work rate test

\begin{tabular}{|c|c|c|c|c|}
\hline Index & Group & $n$ & Mean & $S E M$ \\
\hline Intercept (k) (l) & $\begin{array}{l}\text { Men, } 20-39 \text { years } \\
\text { Men, } 40+\text { years } \\
\text { Women, 20-39 years }\end{array}$ & $\begin{array}{r}7 \\
3 \\
12\end{array}$ & $\begin{array}{l}0.26 \\
0.41 \\
0.28\end{array}$ & $\begin{array}{l}0.02 \\
0.06 \\
0.02\end{array}$ \\
\hline$\frac{\text { Slope } \dot{V} E}{\mathrm{~V}_{\mathbf{T}}}(\mathrm{m})$ & $\begin{array}{l}\text { Men, 20-39 years } \\
\text { Men, 40+ years } \\
\text { Women, 20-39 years }\end{array}$ & $\begin{array}{r}7 \\
3 \\
12\end{array}$ & $\begin{array}{l}47 \cdot 6 \\
64 \cdot 7 \\
84 \cdot 4\end{array}$ & $\begin{array}{r}5 \cdot 6 \\
6 \cdot 9 \\
15 \cdot 9\end{array}$ \\
\hline$\frac{\text { Slope } \dot{V}_{E}}{V_{T}} \times V C$ & $\begin{array}{l}\text { Men, } 20-39 \text { years } \\
\text { Men, } 40+\text { years } \\
\text { Women, 20-39 years }\end{array}$ & $\begin{array}{r}7 \\
3 \\
12\end{array}$ & $\begin{array}{r}76 \cdot 7 \\
114.9 \\
98 \cdot 7\end{array}$ & $\begin{array}{r}7 \cdot 2 \\
17 \cdot 0 \\
15 \cdot 0\end{array}$ \\
\hline $\mathrm{V}_{\mathrm{T}_{20}}(\mathrm{l})$ & $\begin{array}{l}\text { Men, } 20-39 \text { years } \\
\text { Men, } 40+\text { years } \\
\text { Women, 20-39 years }\end{array}$ & $\begin{array}{r}6 \\
3 \\
10\end{array}$ & $\begin{array}{l}0.748 \\
0.725 \\
0.628\end{array}$ & $\begin{array}{l}0.036 \\
0.098 \\
0.039\end{array}$ \\
\hline$V_{T_{30}}(1)$ & $\begin{array}{l}\text { Men, 20-39 years } \\
\text { Men, } 40+\text { years } \\
\text { Women, 20-39 years }\end{array}$ & $\begin{array}{l}4 \\
1 \\
8\end{array}$ & $\begin{array}{l}1.006 \\
1 \cdot 115 \\
0.836\end{array}$ & $\begin{array}{l}0.065 \\
0.059\end{array}$ \\
\hline$V_{T} \max (1)$ & $\begin{array}{l}\text { Men, 20-39 years } \\
\text { Men, } 40+\text { years } \\
\text { Women, 20-39 years }\end{array}$ & $\begin{array}{r}7 \\
3 \\
12\end{array}$ & $\begin{array}{l}0.995 \\
0.979 \\
0.761\end{array}$ & $\begin{array}{l}0 \cdot 164 \\
0 \cdot 246 \\
0 \cdot 092\end{array}$ \\
\hline$\frac{V_{T_{20}}}{V C} \times 100 \%$ & $\begin{array}{l}\text { Men, 20-39 years } \\
\text { Men, } 40+\text { years } \\
\text { Women, 20-39 years }\end{array}$ & $\begin{array}{r}6 \\
3 \\
10\end{array}$ & $\begin{array}{l}40 \cdot 8 \\
41 \cdot 0 \\
42 \cdot 6\end{array}$ & $\begin{array}{l}4 \cdot 2 \\
4 \cdot 7 \\
2 \cdot 8\end{array}$ \\
\hline$\frac{V_{T_{30}}}{V C} \times 100 \%$ & $\begin{array}{l}\text { Men, 20-39 years } \\
\text { Men, } 40+\text { years } \\
\text { Women, 20-39 years }\end{array}$ & $\begin{array}{l}4 \\
1 \\
8\end{array}$ & $\begin{array}{l}46 \cdot 7 \\
38 \cdot 4 \\
50 \cdot 5\end{array}$ & $\begin{array}{l}3 \cdot 0 \\
3 \cdot 7\end{array}$ \\
\hline$\frac{V_{T} \max }{V C} \times 100 \%$ & $\begin{array}{l}\text { Men, } 20-39 \text { years } \\
\text { Men, } 40+\text { years } \\
\text { Women, 20-39 years }\end{array}$ & $\begin{array}{r}7 \\
3 \\
12\end{array}$ & $\begin{array}{l}56 \cdot 4 \\
52 \cdot 5 \\
56 \cdot 4\end{array}$ & $\begin{array}{l}2 \cdot 9 \\
1 \cdot 8 \\
2 \cdot 7\end{array}$ \\
\hline
\end{tabular}

When these results are corrected for the small VC of these scoliotic subjects the abnormalities are reversed (fig 3). The values for $\mathrm{m}$. VCare below normal ( $\mathrm{P}<0.01$ for men; $\mathrm{P}<0.05$ for women), and $\mathrm{V}_{\mathrm{T} 20} / \mathrm{VC}$ and $\mathrm{V}_{\mathrm{T} 30} / \mathrm{VC}$ are above normal $(\mathrm{P}<0.01$ for both sexes). $\mathrm{V}_{\mathrm{T}} \max / \mathrm{VC}$, however, is within the normal range in both sexes.

\section{HEART RATE}

The response of the heart rate in both sexes during the increasing work rate test is displayed in table 4 . The heart rate was significantly faster $(\mathrm{P}<0.01)$ in women than men at $\dot{\mathrm{VO}}_{2} 0.75,1.0,1.5 \mathrm{l} / \mathrm{min}$. However, the difference in slope $\mathrm{HR} / \mathrm{VO}_{2}$ between the women and men aged 20-39 years was not significant.

$\mathrm{HR}_{0} \cdot 75,1.0,1.5$ and slope $\mathrm{HR} / \mathrm{VO}_{2}$ were significantly greater $(\mathrm{P}<0.01)$ in both sexes than in normal subjects (Spiro, 1975) except for $\mathrm{HR}_{1.5}$ in women and slope $\mathrm{HR} / \dot{\mathrm{VO}}_{2}$ in men over 40 . However, these groups contained only two and three subjects respectively. In the 20 who achieved maximal exercise, heart rate ranged from 128 to 201 beats $\mathrm{min}^{-1}$ (mean 168).

\section{ARTERIAL BLOOD GASES}

The $\mathrm{PaO}_{2}$ at rest ranged from 38.0 to $100.5 \mathrm{mmHg}$ $(\mathrm{n}=11$, mean $=73.8, \mathrm{SD}=16.7)$. The $\mathrm{PaCO}_{2}$ at rest ranged from 30.9 to $87.7 \mathrm{mmHg}(\mathrm{n}=11$, mean $=48 \cdot 3$,

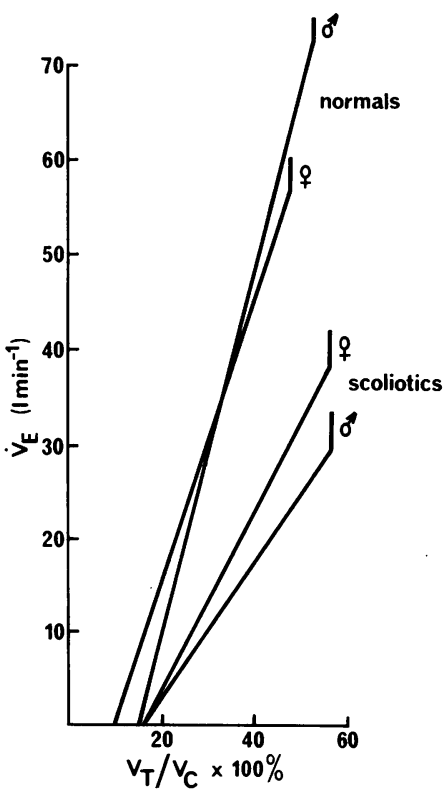

Fig 3 Relation between $\dot{V}_{E}$ and $V_{T} / V C \times 100 \%$ in 26 scoliotic patients and normal subjects (Spiro, 1975).

Table 4 Response of heart rate during increasing work rate test

\begin{tabular}{|c|c|c|c|c|c|}
\hline Index & Group & $n$ & Mean & $S D$ & $S E M$ \\
\hline $\begin{array}{r}\text { Slope } \mathrm{HR} / \mathrm{V}_{2} \\
\text { (beats } / 1 \dot{\mathrm{Vo}_{2}} \text { ) }\end{array}$ & $\begin{array}{l}\text { All } \\
\text { Men, 20-39 years } \\
\text { Men, 40+ years } \\
\text { Women, 20-39 years }\end{array}$ & $\begin{array}{r}26 \\
7 \\
3 \\
13\end{array}$ & $\begin{array}{l}85 \cdot 6 \\
88 \cdot 7 \\
38 \cdot 0 \\
92 \cdot 8\end{array}$ & $\begin{array}{r}39 \cdot 9 \\
32 \cdot 4 \\
7 \cdot 4 \\
30 \cdot 2\end{array}$ & $\begin{array}{r}7 \cdot 8 \\
12 \cdot 2 \\
4 \cdot 2 \\
8 \cdot 4\end{array}$ \\
\hline $\begin{array}{l}\mathrm{HR}_{0} .75 \\
\quad \text { (beats } \min ^{-1} \text { ) }\end{array}$ & Men, $>20$ years & 8 & $114 \cdot 4$ & $9 \cdot 5$ & $3 \cdot 4$ \\
\hline $\begin{array}{l}\mathbf{H R}_{1 \cdot 0} \\
\quad\left(\text { beats } \min ^{-1} \text { ) }\right.\end{array}$ & Men, $>20$ years & 6 & $126 \cdot 8$ & $11 \cdot 1$ & $4 \cdot 6$ \\
\hline $\begin{array}{l}\mathrm{HR}_{1 \cdot 3} \\
\quad \text { (beats } \mathrm{min}^{-1} \text { ) }\end{array}$ & Men, $>20$ years & 2 & $141 \cdot 5$ & $4 \cdot 9$ & $3 \cdot 5$ \\
\hline $\begin{array}{l}\mathbf{H R}_{0.75} \\
\quad\left(\text { beats } \min ^{-1} \text { ) }\right.\end{array}$ & Women, $>20$ years & 10 & $146 \cdot 5$ & $19 \cdot 7$ & $6 \cdot 2$ \\
\hline $\begin{array}{l}\mathbf{H R}_{1 \cdot 0} \\
\quad\left(\text { beats } \mathrm{min}^{-1}\right)\end{array}$ & Women, $>20$ years & 9 & $162 \cdot 8$ & $20 \cdot 0$ & $6 \cdot 7$ \\
\hline $\begin{array}{l}\mathrm{HR}_{1.5} \\
\quad\left(\text { beats } \mathrm{min}^{-1} \text { ) }\right.\end{array}$ & Women, $>20$ years & 2 & 172 & $9 \cdot 9$ & $7 \cdot 0$ \\
\hline
\end{tabular}

$\mathrm{SD}=15 \cdot 9$ ). The changes after exercise were not statistically significant for either $\mathrm{PO}_{2}$ or $\mathrm{PCO}_{2}$.

\section{Discussion}

The results in those with scoliosis show several definite differences from normal. Firstly, $\dot{V}_{2} \max$ was significantly less than normal $(P<0.01)$ for both sexes, even when corrected for total body weight. In 16 of the 20 subjects who exercised maximally (six stopped prematurely due to tiredness) exercise was limited by their ventilation. This contrasts with 
normal subjects whose exercise capacity is circulationlimited. It does however explain why $\dot{V}_{2} \max$ was linearly related in those with scoliosis to two estimates of maximal ventilation, FEV 1 and VE max (fig 4). While this does not hold for normal subjects, similar equations have been obtained in chronic bronchitics, whose exercise is also ventilation-limited (Spiro et al, 1975). In the subjects of the present study the prediction formulae for $\dot{V}_{2}$ max were

$$
\begin{aligned}
\dot{\mathrm{VO}}_{2} \max = & 0.53 \mathrm{FEV}_{1}+0.365 \mathrm{l} / \mathrm{min} \\
& (\mathrm{n}=20, \mathrm{r}=0.932, \mathrm{P}<0.001) \\
= & 0.024 \mathrm{VE} \max +0.1991 / \mathrm{min} \\
& (\mathrm{n}=20, \mathrm{r}=0.953, \mathrm{P}<0.001)
\end{aligned}
$$

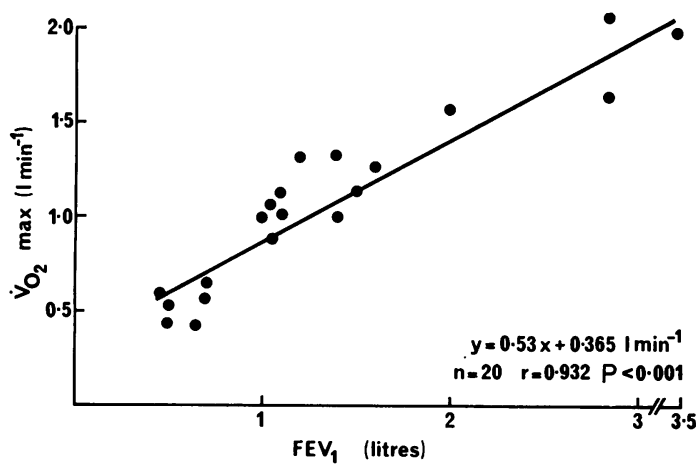

(a)

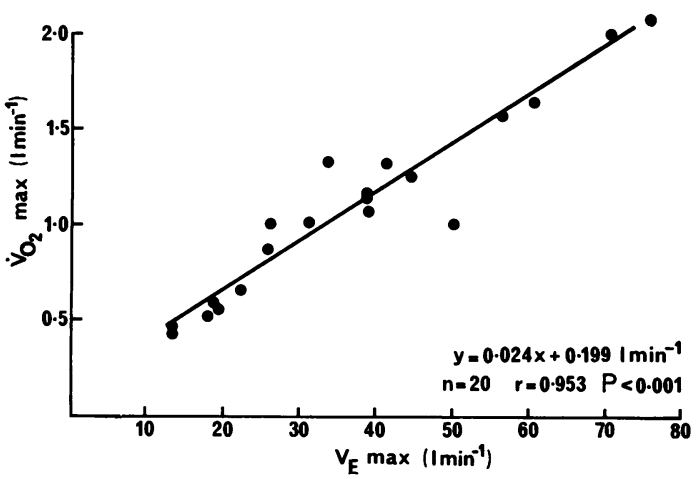

(b)

Fig 4 Relation between $\dot{V}_{O 2} \max$ and (a) FEV (b) $\dot{V}_{E} \max$.

$\dot{V}$ max was a normal proportion (70\%) of the MVV (ie the dyspnoeic index was normal), but in absolute terms it was greatly reduced. For the men the mean $\dot{V}$ max was only $41.961 / \mathrm{min}$, which is $35.2 \%$ normal (Cotes et al, 1969). In the women it was $32.09 \mathrm{l} / \mathrm{min}$, which is $40.4 \%$ normal (Cotes et al, 1969). VE max was linearly related to $\mathrm{FEV}_{1}, \mathrm{VC}$, and MVV by the following equations (fig 5)

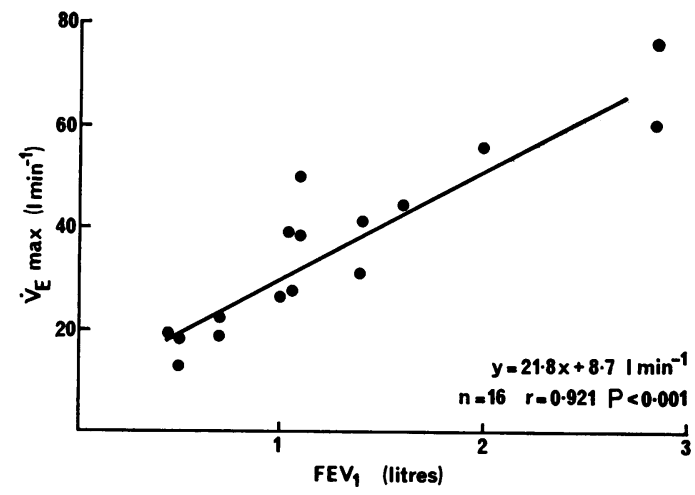

(a)

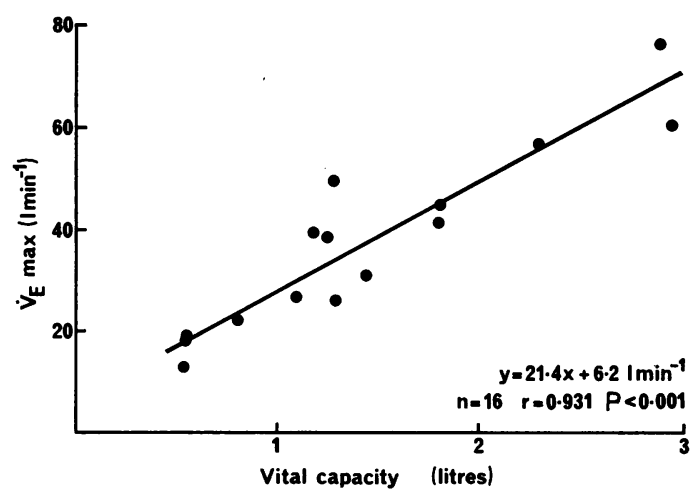

(b)

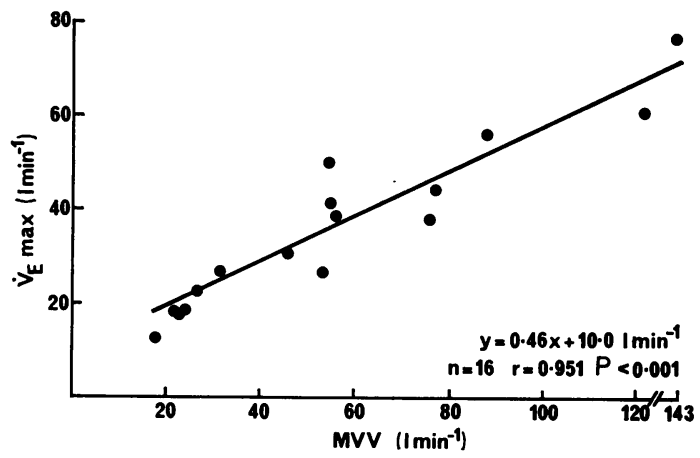

(c)

Fig 5 Relation between $\dot{V}_{E} \max$ and (a) FEV,$(b) V C$, (c) $M V V$.

$$
\begin{aligned}
\dot{V} \max = & 21.8 \mathrm{FEV}_{1}+8.71 / \mathrm{min} \\
& (\mathrm{n}=16, \mathrm{r}=0.921, \mathrm{P}<0.001) \\
= & 21.4 \mathrm{VC}+6.21 / \mathrm{min} \\
& (\mathrm{n}=16, \mathrm{r}=0.931, \mathrm{P}<0.001) \\
= & 0.46 \mathrm{MVV}+10.01 / \mathrm{min} \\
& (\mathrm{n}=16, \mathrm{r}=0.951, \mathrm{P}<0.001)
\end{aligned}
$$


A similar relationship, but with a larger intercept, was obtained for chronic bronchitics by Spiro et al (1975).

Although the gross diminution in $\dot{V}_{E} \max$ is the main cause of the abnormally low $\dot{V}_{2} \max$, the minute ventilation for any given $\dot{\mathrm{V}}_{2}$ was also significantly greater than normal. Thus not only was the upper limit of minute ventilation decreased, but the subjects hyperventilated relative to their work rate as well. There was no correlation between slope $\dot{\mathrm{VE}} / \dot{\mathrm{VO}}_{2}$ and the angle of scoliosis, $\mathrm{VC}, \mathrm{PaO}_{2}, \mathrm{PaCO}_{2}$, or $\mathrm{pH}$ before or after exercise or to the change in any of these during exercise. The extra work expended in hyperventilating with a stiff deformed thorax decreases the amount of energy available for performing external work.

The tidal volume increased linearly with ventilation until $V_{T} \max$ was reached. Increase in ventilation beyond this point was accomplished by an increase in respiratory frequency. This is the normal pattern (Hey et al, 1966). The slope $\dot{V}_{\mathrm{E}} / \mathrm{V}_{\mathrm{T}}(\mathrm{m})$ was greater in those with scoliosis than normal, and this is also reflected in the small values for the tidal volume at minute ventilations of 20 and $30 \mathrm{l} / \mathrm{min}$. If the tidal volumes are corrected for the small vital capacities of these subjects, however, $\mathrm{m}$ becomes less than normal and $\mathrm{V}_{\mathrm{T} 20} / \mathrm{VC}$ and $\mathrm{V}_{\mathrm{T} 30} / \mathrm{VC}$ are above normal. Thus although in absolute volumes the $V_{T}$ of those with scoliosis is less than normal at any given minute ventilation, it is actually a larger percentage of their vital capacity than is normal. They are partially compensating for their small $\mathrm{VC}$ by using a greater proportion of it in tidal breathing at any given $\dot{V} E$. Their maximal tidal volumes are also small, although $\mathrm{V}_{\mathrm{T}} \mathrm{max} / \mathrm{VC}$ was normal.

Almost all the indices of the heart rate response to exercise are significantly above Spiro's (1975) normal ranges. Cotes et al (1973), however, have shown that the tachycardia of exercise is inversely proportional to the fat free mass (FFM):

slope $\mathrm{HR} / \dot{\mathrm{VO}}_{2}=2580 \mathrm{FFM}^{-1}+1585$ beats $/ \mathrm{min}$ (coefficient of variation $=11.8 \%$ )

where FFM is expressed in $\mathrm{kg}$.

The mean FFM of those with scoliosis was only $36.4 \mathrm{~kg}$ (SD $9.6 \mathrm{~kg}$ ). This correction is therefore quantitatively important. If it is applied to the nonparalytic subjects the observed/predicted slope HR/ $\dot{\mathrm{VO}}_{2}$ is $1.02(\mathrm{n}=17, \mathrm{SEM}=0.08)$ but for those with scoliosis with neurological or muscular diseases it is $1.38(n=9, \operatorname{SEM}=0 \cdot 12)$. In the former group the tachycardia is not abnormal but is a physiological consequence of their small size. The tachycardia in the subjects with neurological or muscular disease remains unexplained. It may be an artefact since Cotes's correction formula depends on a normal muscle: bone ratio and these patients, especially those who have had poliomyelitis, probably have less? muscle than normal. If this is so it would invalidate the use of this formula for these patients and could $\frac{\bar{\omega}}{\partial}$ explain the apparent tachycardia.

I would like to thank Dr F J Prime for his advice and encouragement with this work, Dr P A Zorab for allowing me to study patients under his care, $M r R \vec{\omega}$ Madgwick for his skilled technical help, and Mrs $\mathrm{J} L \stackrel{\circ}{\circ}$ MacGuigan for typing the manuscript.

I am grateful to the Research Committee of the $\underset{\omega}{\omega}$ Brompton Hospital and to Boehringer Ingelheim Ltd ${ }_{A}$ for their grants during the tenure of my appointment of at the Cardiothoracic Institute.

\section{References}

Anthony, A J (1930). Untersuchungen über Lungenvolumina und Lungenventilation. Deutches Archiv für klinische Medizin, 167, 129-176.

Bergofsky, E H, Turino, G M, and Fishman, A P (1959). Cardiorespiratory failure in kyphoscoliosis. Medicine, 38, 263-317.

Bruce, R A, Kusumi, F, and Hosmer, D (1973). Maximal oxygen intake and nomographic assessment of functional aerobic impairment in cardiovascular disease. American Heart Journal, 85, 546-562.

Cobb, J R (1948). Outline for the study of scoliosis. American Academy of Orthopaedic Surgeons, Instruc- $\bar{O}$ Course Lectures, 5, 261-275.

Cotes, J E (1969). Relationships of oxygen consumption, ventilation, and cardiac frequency to body weight during standardised submaximal exercise in normal subjects. Ergonomics, 12, 415-427.

Cotes, J E, Berry, G, Burkinshaw, L, Davies, C T M, ֻ Hall, A M, Jones, P R M, and Knibbs, A V (1973). Cardiac frequency during submaximal exercise in 3 . young adults: relation to lean body mass, total body potassium, and amount of leg muscle. Quarterly Journal of Experimental Physiology, 58, 239-250.

Cotes, J E, Davies, C T M, Edholm, O G, Healy, M J R, 윽 and Tanner, J M (1969). Factors relating to the aerobic $D$ capacity of 46 healthy British males and females, ages 18 to 28 years. Proceedings of the Royal Society B, 174, N 91-114.

Durnin, J V G A, and Womersley, J (1974). Body fat N assessed from total body density and its estimation $N$ from skinfold thickness: measurements on 481 men and women aged from 16 to 72 years. British Journal of Nutrition, 32, 77-97.

Godfrey, S (1974). Exercise Testing in Children. Applica- $\mathbb{D}$ tions in Health and Disease. W B Saunders, London.

Hey, E N, Lloyd, B B, Cunningham, D J C, Jukes, M G M, and Bolton, D P G (1966). Effects of various 흥 respiratory stimuli on the depth and frequency of $\stackrel{\mathbb{O}}{\mathcal{O}}$ breathing in man. Respiratory Physiology, 1, 193-205.

Hippocrates. The Genuine Works of Hippocrates. Trans- 응 lated from the Greek with a preliminary discourse and annotations by F Adams (1849), vol 2, p 604. The of Sydenham Society, London. 
Hutchinson, J (1844). Contributions to vital statistics obtained by means of a pneumatic apparatus for valuing the respiratory powers with relation to health. Journal of the Statistical Society of London, 7, 193-212.

Samuelsson, S (1950). Chronic Cor Pulmonale. A Clinical Study, translated by A la Cour, pp 127-158. Munksgaard, Copenhagen.

Spiro, S G (1975). Cardiorespiratory Adaptations at the Start of Exercise in Normal Subjects and Patients with Chronic Obstructive Bronchitis. MD Thesis. University of Manchester.

Spiro, S G, Hahn, H L, Edwards, R H T, and Pride, N B (1975). An analysis of the physiological strain of submaximal exercise on patients with chronic obstructive bronchitis. Thorax, 30, 415-425.

Spiro, S G, Juniper, E, Bowman, P, and Edwards, R H T (1974). An increasing work rate test for assessing the physiological strain of submaximal exercise. Clinical Science and Molecular Medicine, 46, 191-206. Taylor, H L, Wang, Y, Rowell, L, and Blomqvist, G (1963). The standardisation and interpretation of submaximal and maximal tests of working capacity. Pediatrics, 32, 703-722.

Wlodyka, P, and Wierusz, L (1974). Trening Wydolnosci Krazeniowo-oddechowej u chorych z bocznym skrzywieniem kregoslupa i deficytem oddechowym. Chirurgia Narzadow Ruchu Ortopedia Polska, 39, 481-486.

Requests for reprints to: Dr J M Shneerson, Department of Respiratory Physiology, Cardiothoracic Institute, Brompton Hospital, London SW3 6HP. 